\title{
Low Water Productivity for Rice in Bihar, India-A Critical Analysis
}

\author{
Omaid Najmuddin ${ }^{1,2,3, *}$, Golam Rasul ${ }^{1}$, Abid Hussain ${ }^{1}$ (D), David Molden ${ }^{1}$, Shahriar Wahid ${ }^{1,4}$ \\ and Bijan Debnath ${ }^{1}$ \\ 1 International Centre for Integrated Mountain Development (ICIMOD), Lalitpur 44700, Nepal; \\ golam.rasul@icimod.org (G.R.); abid.hussain@icimod.org (A.H.); david.molden@icimod.org (D.M.); \\ swahid@gmail.com (S.W.); bijan.debnath@outlook.com (B.D.) \\ 2 Institute of Geographic Sciences and Natural Resources Research, Chinese Academy of Sciences, Beijing \\ 100101, China \\ 3 University of Chinese Academy of Sciences, Beijing 100049, China \\ 4 Commonwealth Scientific and Industrial Research Organisation (CSIRO), Canberra 2601, Australia \\ * Correspondence: omaid_najmuddin@yahoo.com or omaid@igsnrr.ac.cn; Tel.: +86-130-5135-8505
}

Received: 28 April 2018; Accepted: 8 August 2018; Published: 14 August 2018

\begin{abstract}
Rice is the most important crop for food security and livelihoods of the rural population in Bihar, India. In spite of good soil and water resources, rice water productivity (WP) is very low in Bihar. Trends in WP and key factors influencing WP over 20 years (1991-2010) in 11 Bihar districts were analysed using panel data to help elucidate reasons for low WP values. The annual average rice yield of $938 \mathrm{~kg} / \mathrm{ha}$, WP of $0.22 \mathrm{~kg} / \mathrm{m}^{3}$, and marginal physical productivity (MPP) of $249 \mathrm{~g} / \mathrm{m}^{3}$ are very low in Bihar compared to both the national average for India and other rice growing areas in the world. Rice WP and MPP were higher for the garma (dry) season than for the kharif (monsoon) season. Temporal analysis showed that WP was slowly declining in most districts, while spatial analysis showed a significant variation in WP across the districts. Regression analysis showed that the availability of irrigation facilities, occurrence of flood and drought, and cropping intensity had significant influence on rice WP. Causes for temporal and spatial changes in WP are highlighted and actions to improve rice WP in Bihar are suggested.
\end{abstract}

Keywords: water productivity; marginal physical productivity; spatiotemporal perspective; Koshi River basin; Bihar; India

\section{Introduction}

Worldwide, the demand for water is increasing and the gap between demand and supply is widening, especially in areas with rapid population growth and increased economic activities, i.e., rural and urban development, industrialization and expansion of irrigation systems [1-4]. Population means an enhanced demand for food, while increase in non-agricultural economic activities results in increased competition among different sectors for the water needed to grow that food [5-7]. Global warming due to climate change is likely to further increase agricultural water requirement as a result of increased evapotranspiration (ET) [2,8,9]. The resultant water scarcity will challenge the agricultural sector to increase production using less water, in other words by improving agricultural water productivity (WP) [6,10-15]. Improving agricultural WP remains one of the biggest issues in food production and ensuring sustainable livelihoods $[6,9,16]$.

The challenge is particularly acute in India as rice, the staple, is a water intensive crop. Across Asia, rice consumes nearly $50 \%$ of the total freshwater used in agriculture [6,17]. In India, agriculture and livestock production consume $91 \%$ of total withdrawn water (municipalities $7 \%$, industry $2 \%$ ), 
making rice the single largest consumer of water [18]. India is facing the major challenge of producing increased amounts of food required for a burgeoning population-but with less water, as quantity and reliability of water supply has become an issue. Overall rice WP in India is relatively low in comparison to rice growing areas of other countries [19]. In Nanchang (China), Kadawa, (Nigeria) and Luzon (Philippines), rice WP is $1.84 \mathrm{~kg} / \mathrm{m}^{3}, 0.59 \mathrm{~kg} / \mathrm{m}^{3}$ and $1.39-1.61 \mathrm{~kg} / \mathrm{m}^{3}$, respectively. In Echuca, Australia, WP ranges from 0.70 to $0.75 \mathrm{~kg} / \mathrm{m}^{3}$, and in different areas of United States of America, it ranges from 0.88 to $1.44 \mathrm{~kg} / \mathrm{m}^{3}$ [19]. A recent study [20] from India revealed that rice WP ranges from $0.24 \mathrm{~kg} / \mathrm{m}^{3}$ to $0.57 \mathrm{~kg} / \mathrm{m}^{3}$ in rice growing states. While WP in Punjab, West Bengal, and Assam was relatively high (more than $\left.0.50 \mathrm{~kg} / \mathrm{m}^{3}\right)$, it was very low in Bihar $\left(0.28 \mathrm{~kg} / \mathrm{m}^{3}\right)$, Madhya Pradesh $\left(0.25 \mathrm{~kg} / \mathrm{m}^{3}\right)$ and Karnataka $\left(0.24 \mathrm{~kg} / \mathrm{m}^{3}\right)$. In Bihar, where soil conditions and weather are good, and rice is a major crop and staple food, low WP is a serious concern.

With a large population (over 104 million), Bihar is one of the poorest and most food-insecure states in India. Improving rice WP is critically important for increasing food security and water security. Bihar is endowed with good soil and is relatively rich in water resources, with average annual precipitation of over $1200 \mathrm{~mm}$ and several large rivers. More than $28 \%$ of the population lives within the Koshi River basin, which covers one-third of the state's land area [21,22]. The $3000 \mathrm{~km}$ long Koshi River is a major tributary of the Ganges; it originates in the southern part of the Tibetan plateau and passes through China and Nepal before entering Bihar.

About $80 \%$ of Bihar's population depends on agriculture, which contributes $60 \%$ to the state's Gross Domestic Product (GDP) [23]. However, despite its importance to livelihoods and the economy, the agricultural sector has stagnated. The higher growth experienced between 1981 and 1991 has slowed [24] despite a substantial increase in tube well irrigation [25]. The yields obtained by most farmers are low and leave little surplus for the market [25]. Rice is the staple crop and is grown over a large area [26]. For the majority of farming households, it is the main source of income and livelihood. However, rice productivity in the state is among the lowest in India [27] and two and half times lower than in similar rice growing districts in the Nepal part of the Koshi River basin [28]. In Bihar, the rice crop depends on both rainfall and irrigation, with tube wells providing water for around $62 \%$ of the total irrigated area. Most tube wells are privately owned, which creates an informal water market $[29,30]$. The remainder of the irrigated area uses water drawn from the Koshi River. The Bihar part of the Koshi River basin has attracted considerable interest from researchers and policy makers as a result of its unique water management problem-too little water for much of the year, alternating with too much during the monsoon. In such a situation, rice production is a gamble, with win or loss decided by water availability and access [28]. It is essential to enhance the WP of rice in Bihar to support economic development, and increase food security and the sustainability of the water resources [31].

The key challenge before agricultural planners in Bihar is how to increase WP so that more food can be produced and provided to a large food insecure population using available water resources. However, in order to design effective policies for increasing WP, it is first necessary to understand the factors that influence present levels of productivity and the variation across districts and regions. Specifically, understanding spatiotemporal variation of WP in rice cultivation, and identifying the factors affecting it, will help in planning for improving rice WP and water management. However, in contrast to the substantial research on land and labour productivity, there has been little research on spatiotemporal variation in WP in Bihar [32]. To fill this gap, this paper investigates the factors that influence rice WP in Bihar by taking a multidisciplinary approach.

Accurate measurement of WP at a larger scale, i.e., basin level, has remained a challenge [7]. There are several farm level studies on WP, with limited value for policy actions at a larger scale [33]. With recent advancements in remote sensing and modeling, researchers have applied remote sensing approaches to measuring macro scale crop WP [33-35]. Despite its many advantages, remote sensing depends largely on complicated modeling that requires cost intensive ground observation data [36-38], and misses out in-depth analysis of climatic and socioeconomic drivers of WP. In view of that, this study 
adopted a multidisciplinary approach, using a combination of statistical and GIS techniques and econometric modeling, to estimate rice WP, analyze spatiotemporal variation, and investigate the effect of key factors on WP, using panel data of 20 years (1991-2010) for 11 districts of Bihar state, India. This multidisciplinary approach provides more validity and reliability to results, and increases the likelihood of the study findings being used for policy formulation. To the best of our knowledge, such multidisciplinary studies on crop WP are rare in existing literature. In the Koshi River basin, some studies [25,30,39-42] identified key technological, climatic, and socioeconomic factors and their influence on rice WP, but there has been no quantitative investigation of the effect of these factors. Particularly, climatic factors such as variation in annual rainfall and resultant droughts and floods may have a marked impact on rice yield and WP [30,43], particularly in Bihar [28,44]. It may have serious implications for food security and socio-economic development [20].

\section{Data and Methodology}

To estimate rice WP, we used a multidisciplinary approach, and analyzed spatiotemporal variation of WP, and investigated the effect of key factors influences WP by using the panel data. This section describes the study area, data handling methods, and statistical and GIS techniques and explains the econometric model used in the study.

\subsection{Study Area}

The Koshi river basin in Bihar was selected because it is an area that is theoretically rich in water but has poor agricultural productivity and very low WP for rice, the staple crop. Rice is a major factor in food and livelihood security for the majority of the rural population in the state. The study area covered 11 districts in Bihar that are directly or indirectly affected by the Koshi River and its hydrology (Figure 1). In these districts, rice is grown in autumn, winter, and summer. The rice is named according to the season of harvest rather than sowing. Autumn rice (bhadai) is sown in May-July and harvested in September-October, and winter rice (aghani) is sown in July-September and harvested in November-December. Aghani and bhadai are together called as kharif rice or monsoon rice. Summer rice (garma) rice is sown in January-February and harvested in May-June [45]. Garma rice is also called as dry season rice. To understand the inter-seasonal differences of WP, the study compared kharif with garma rice crops.

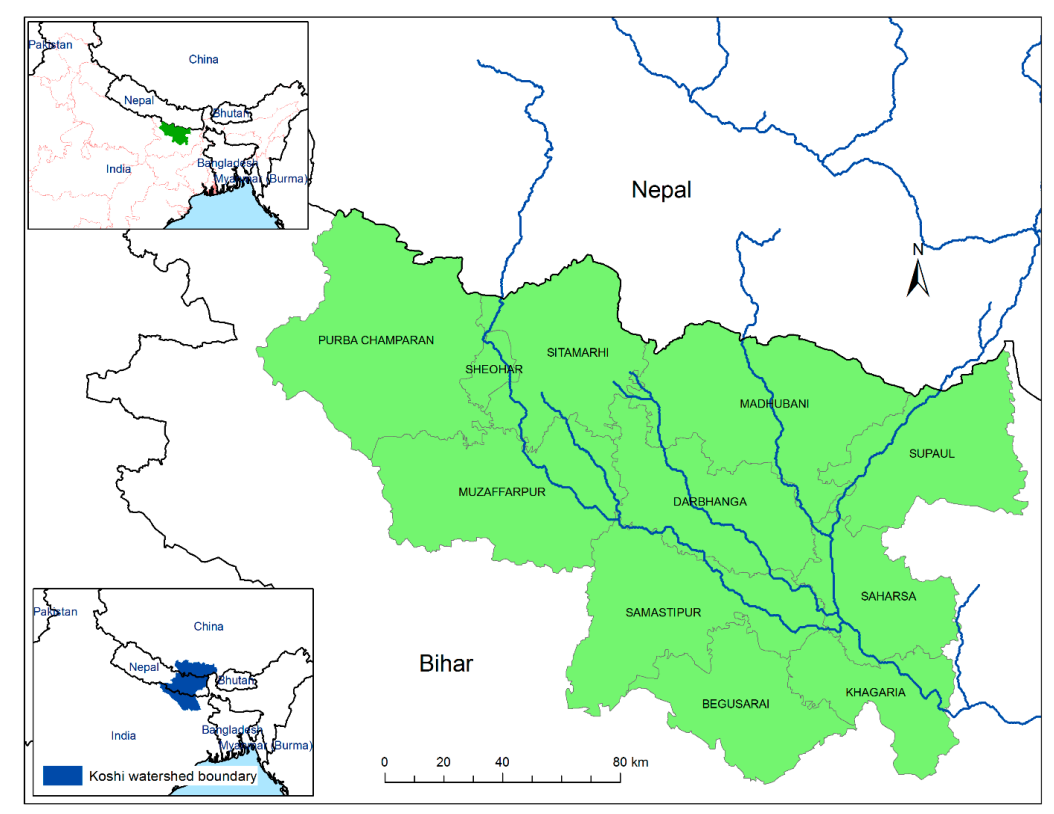

Figure 1. The study area-11 districts in Bihar that lie wholly or partly within the Koshi River basin. 


\subsection{Data Handling}

The study was based on district level panel data on rice production related variables and flood and drought. Data was procured for the 11 districts for a 20-year period (1991-2010). The main sources of agricultural data were the Bihar Department of Agriculture [46], 'Bihar through Figures' [22], and the 'Bihar Statistical Hand Book' [47-50]. Some crop data were purchased online from Districts of India [51]. The variables related to rice production included yield, irrigated area, crop area under high yielding variety (HYV), fertilizer use, and number of agricultural credit accounts. Flood and drought data were obtained from the Disaster Management Department [52]. Other crop information, for example crop coefficients and crop growth stages, was obtained from the FAO crop evapotranspiration guidelines for computing crop water requirements [51].

Climate data were obtained from the Government of India Meteorological Department. Station-based climate datasets, collected on a daily basis, were acquired for a 20-year period and computed on an average monthly basis to facilitate understanding of the climate pattern. The climate data were used to generate a climate surface over the study area using different interpolation techniques.

\subsection{Measuring Water Productivity}

The term crop WP means different things for different stakeholders [12]. For plant physiologists it is the quantity of dry matter produced per unit of water that is transpired by the plant; for farmers, it is the quantity of yield produced per unit of water supplied to the field [53]. Similar, economists see water as an input for production and measure WP as a change in output (in monetary value) for each unit of water [53].

In agricultural management, crop WP is an important indicator to assess the performance of agriculture systems in converting water (input) into agricultural output [34-54]. The output can be represented in both physical and economic units [55]. The ratio of crop yield (kg/ha) to the amount of water use $\left(\mathrm{m}^{3} / \mathrm{ha}\right)$ represents a physical unit of WP, whereas the economic WP $\left(\$ / \mathrm{m}^{3}\right)$ represents economic benefits per unit of water used [34]. Similarly, WP studies at different scales determine the direction of WP investigation. For instance, focusing simply on WP by considering total water diverted into fields, or irrigation efficiency, is not sufficient when making decisions across a river basin, since some part of the diverted water may be reused elsewhere in the basin [7].

Following Molden and Sakthivadivel [7], WP in this study was defined as 'crop yield per unit of consumptive water use (CWU)'. The approach used for calculating crop WP is summarized in Figure 2 in the form of a flow chart.

CWU was estimated using the following equation [56]:

$$
\mathrm{CWU}=\left\{\begin{array}{c}
\sum_{\text {keseasons }} \operatorname{IRA}_{l K} \sum_{j \in m o n t h} \sum_{i \in g r o w t h} k c_{k i}^{1} \times E T p_{j} \times \frac{d_{i j}}{n_{j}} \text { for irrigated crops } \\
\sum_{\text {keseasons }} \operatorname{RFA}_{l K} \sum_{j \in m o n t h} \sum_{i=\text { growth }} \min \left(k c_{k i}^{1} \times E T p_{j}, E f f r f_{j}\right) \times \frac{d_{i j}}{n_{j}} \text { for rainfed crops }
\end{array}\right.
$$

where IRA $\mathrm{Ik}_{l k}$ and $\mathrm{RFA}_{l k}$ represent irrigated and rain-fed areas, respectively, of the $l$ th crop in the $k$ th season; $i$ is the number of growth periods in a cropping season; $d_{i j}$ is the number of days in the $j$ th month in the $i$ th crop growth period; $n_{j}$ is the number of days in the $j$ th month; $k c$ is the crop coefficient of the crop in the $i$ th growth period of the $k$ th season; and $E f f r f_{j}$ is the effective rainfall for the period of the month in which the crop is grown.

Two forms of Equation (1) are based on the following assumptions:

(a) Irrigation meets the full water requirements of the crop. In reality this may not always be the case, especially in water-scarce areas and where farmers do not have full control over irrigation. However, in the absence of any other dependable information, the assumption was made that there was no deficit in irrigation water. 
(b) The rain-fed crop does not receive its full water requirement due to dependence on rainfall; thus, the model uses the minimum values for crop ET, and $E f f r f_{j}$ for rain-fed crop water productivity.

The station level ET for the crop season was estimated by utilizing the daily maximum and minimum temperature data and applying Penman-Monteith missing data equation [51]. In 1948, Penman combined energy balance with the mass transfer method and developed the original equation for calculating ET [51]. The original Penman-Monteith equation requires input data of climatological records, i.e., sunshine, temperature, humidity and wind speed to calculate ET. However, if climatological records of sunshine, humidity and wind speed are missing and only air-temperature data is available, the adjusted Penman-Monteith equation (Equation (2)) can be adopted for calculating ET.

$$
\mathrm{ET}_{\mathrm{o}}=0.0023\left(\mathrm{~T}_{\text {mean }}+17.8\right)\left(\mathrm{T}_{\max }-\mathrm{T}_{\min }\right) 0.5 \mathrm{R}_{\mathrm{a}}
$$

where $\mathrm{ET}_{\mathrm{O}}$ refers to reference evapotranspiration, $\mathrm{T}_{\text {mean }}, \mathrm{T}_{\max }$ and $\mathrm{T}_{\min }$ represent respectively maximum, minimum and mean air-temperature $\left({ }^{\circ} \mathrm{C}\right)$; and $\mathrm{R}_{\mathrm{a}}$ represents solar radiation.

The $R_{a}$ was estimated by utilizing the adjusted Hargreaves' radiation equation [51]. The Hargreaves' radiation formula is presented below:

$$
\mathrm{Rs}=\mathrm{k}_{\mathrm{Rs}} \sqrt{\left(\mathrm{T}_{\max }-\mathrm{T}_{\min }\right)} \mathrm{R}_{\mathrm{a}}
$$

where $R_{a}$ refers to extraterrestrial radiation [Mega Joule per square meter per day].

The adjustment coefficient $\mathrm{k}_{\mathrm{RS}}$ differs for 'interior' or 'coastal' regions: for 'interior' locations it is defined @ 0.16; and for 'coastal' environment, it is defined @ 0.19.

To calculate the effective rainfall in the respective districts, the CROPWAT [57] method was used. After the estimation of station level ET and effective rainfall, GIS interpolation technique was used to average them over each district, as used elsewhere [58-63].

The district level ET and effective rainfall information together with crop information (i.e., crop calendar and growth stages, canopy coefficient, and area) were then integrated into equation 1 to calculate the CWU of rice. The rice yield figures of the respective districts were then divided by their total district CWU to estimate rice WP $\left(\mathrm{kg} / \mathrm{m}^{3}\right)$ for each district.

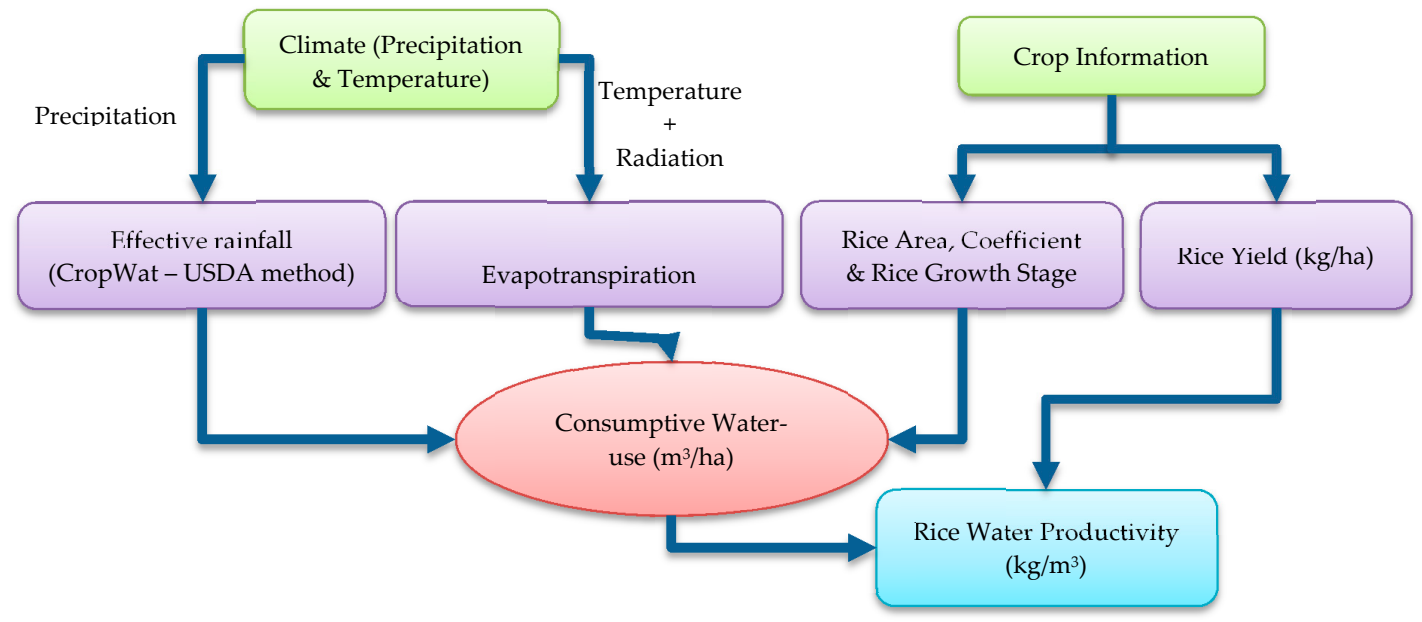

Figure 2. Flow chart for computing water productivity of rice.

\subsection{Measuring MPP of CWU}

Economists apply several techniques to estimate agricultural inputs-use efficiency, i.e., contribution of a particular input in production $[64,65]$. One of the important techniques is to estimate marginal physical productivity (MPP) of farm inputs. While many researchers estimate MPP at farm 
levels to understand the optimum allocation (equilibrium point) of farm inputs in the production process [66], we conducted season-wise MPP analysis of CWU to further deepen the analysis of WP. The MPP of CWU was estimated for kharif and garma seasons to know how much rice was produced when the same unit of water was used under different farm management conditions in the two seasons.

The analytical techniques for estimating MPP range from farm budgets or programming models to statistical relationship of inputs and yields. This study applied the most widely used Cobb-Douglas production function to estimate MPP of water use in rice production, because it is relatively more accurate in estimation $[63,67]$. The function used in this study is presented below:

$$
\log Y_{i}=\alpha+\beta \log X_{i}
$$

Marginal Physical Productivity (MPP) of water $=\beta \times$ Average Physical Productivity (APP). Where $Y_{i}=$ per ha yield gained, $X_{i}=$ per ha consumptive water use (CWU), $\alpha=$ Constant and $\beta=$ Coefficient of $\log X_{i}$

$$
\text { Average Physical Productivity }(\text { APP })=\frac{Y_{i}}{X_{i}}
$$

\subsection{Factors Affecting Rice Water Productivity}

This study used a fixed effects model to analyze panel data and investigate the influence of various socioeconomic, climatic, and technological factors on WP. In view of the type of data (panel data), and their nature (small sample), a fixed effects model was most appropriate as it provides unbiased estimates of coefficients for small samples if the model is linear in parameters and the observations are assumed to be independent across individuals but not necessarily across time [68-70]. To deal with the problem of endogeneity due to simultaneity in the WP function, a fixed-effects two-stage least square model was used (Equation (6)).

$$
\mathrm{y}_{\mathrm{it}}=\mathrm{Y}_{\mathrm{it}} \gamma+\mathrm{X}_{1 \mathrm{it}} \beta+\mu_{\mathrm{i}}+v_{\mathrm{it}}=\mathrm{Z}_{\mathrm{it}} \delta+\mu_{\mathrm{i}}+v_{\mathrm{it}}
$$

where $y_{i t}$ is a dependent variable; $Y_{i t}$ is a $1 \times g_{2}$ vector of observations on $g_{2}$ endogenous variables included as covariates, these variables are allowed to correlate with $v_{i t} ; X_{1 i t}$ is a $1 \times \mathrm{k}_{1}$ vector of observations on the exogenous variables included as covariates. Both endogenous and exogenous covariates can be expressed as $Z_{i t}=\left[Y_{i t} X_{i t}\right]$. In Equation (6), $\gamma$ is $g_{2} \times 1$ vector of coefficients; $\beta$ is a $k_{1}$ $\times 1$ vector of coefficients; and $\delta$ is a $K \times 1$ vector of coefficients, where $K=g_{2}+k_{1} ; v_{\text {it }}$ is idiosyncratic error term that is uncorrelated with exogenous variables $X_{i t} ;$ and $\mu_{i}$ is unobserved fixed effect.

A large number of socioeconomic, climatic, and technological variables were considered, but due to constraints posed by the limited availability of panel data at district level, only seven variables (six independent and one instrumental) were examined for influence on WP:

- $\mathrm{X}_{1}=$ proportion of irrigated area to total area under rice cultivation

- $\mathrm{X}_{2}=$ incidence of drought $(\mathrm{D}=1$ if drought observed in a particular year; 0 if not observed)

- $\mathrm{X}_{3}=$ cropping intensity $(\%) \mathrm{X}_{4}=$ proportion of area under HYV to total area under rice cultivation (\%)

- $X_{5}=$ fertilizer use in gross cropped area $(\mathrm{kg} / \mathrm{ha})$

- $\mathrm{X}_{6}=$ incidence of flood ( $\mathrm{D}=1$ if flood observed in a particular year; 0 if not observed)

- $\quad X_{7}=$ number of agricultural credit accounts as a proxy for supply of credit to rice farmers

The variable $\mathrm{X}_{4}$ was suspected to be endogenous due to reverse causality (simultaneity) with WP because the variable of yield was used in the estimation of WP. To address the problem of endogeneity, an instrumental variable $X_{7}$ was identified through a series of regressions. It is strongly correlated to $\mathrm{X}_{4}$ but has a statistically nonsignificant relationship with WP. After adding the variables, Equation (6) can be expressed in the form of below equations. 


$$
\begin{gathered}
\mathrm{WP}_{\mathrm{it}}=\mathrm{X}_{1 \mathrm{it}} \delta_{1}+\mathrm{X}_{2 \mathrm{it}} \delta_{2}+\mathrm{X}_{3 \mathrm{it}} \delta_{3}+\widehat{X}_{4 \mathrm{it}} \delta_{4}+\mathrm{X}_{5 \mathrm{it}} \delta_{5}+\mathrm{X}_{6 \mathrm{it}} \delta_{6}+\mathrm{v}_{\mathrm{it}} \text { (Stage 2) } \\
\widehat{X}_{4 \mathrm{it}}=\mathrm{X}_{1 \mathrm{it}} \pi_{1}+\mathrm{X}_{2 \mathrm{it}} \pi_{2}+\mathrm{X}_{3 \mathrm{it}} \pi_{3}+\mathrm{X}_{5 \mathrm{it}} \pi_{5}+\mathrm{X}_{6 \mathrm{it}} \pi_{6}+\mathrm{X}_{7 \mathrm{it}} \pi_{6}+\mu_{\mathrm{it}} \text { (Stage 1) }
\end{gathered}
$$

$\mathrm{X}_{4}$ is an endogenous variable. In first stage, the value of $\mathrm{X}_{4}$ is derived from which included all exogenous independent variables and an instrumental variable $X_{7}$. In second stage, fitted value of $X_{4}$ derived from Equation (8) was plugged into Equation (7) to estimate the WP function.

\section{Result and Discussion}

\subsection{Water Productivity}

The WP of rice was estimated across seasons and districts. Table 1 shows the spatial distribution of WP (values by district) for kharif, garma, and total annual rice; the percentage difference in WP between garma rice and kharif and total annual rice; and, the relative variability (coefficient of variation) of WP for the different types of rice (relative variability chosen rather than absolute variability, i.e., standard deviation).

Two districts (Muzaffarpur and Sheohar) had a relatively higher WP $\left(>0.30 \mathrm{~kg} / \mathrm{m}^{3}\right)$ for garma rice and one (Samastipur) a relatively lower value $\left(<0.22 \mathrm{~kg} / \mathrm{m}^{3}\right)$, while no districts had a WP above $0.30 \mathrm{~kg} / \mathrm{m}^{3}$ for kharif rice, and five districts (Begusarai, Darbhanga, Khagaria, Madhubani, and Samastipur) had a value below $<0.22 \mathrm{~kg} / \mathrm{m}^{3}$. The results for total annual rice WP were similar to those for kharif rice as kharif is the dominant rice crop (Table 1 ).

\begin{tabular}{|c|c|c|c|c|c|c|c|c|c|c|c|}
\hline \multirow[t]{2}{*}{ District } & \multicolumn{3}{|c|}{ Rice WP $\left(\mathrm{kg} / \mathrm{m}^{3}\right)$} & \multicolumn{2}{|c|}{$\begin{array}{l}\% \text { Difference } \\
\text { of Garma Rice } \\
\text { WP to }\end{array}$} & \multicolumn{3}{|c|}{$\begin{array}{c}\text { Coefficient of Variation } \\
(\%)\end{array}$} & \multicolumn{3}{|c|}{ Rice Yield (kg/ha) } \\
\hline & Kharif & Garma & Annual & Kharif & Annual & Kharif & Garma & Annual & Kharif & Garma & Annual \\
\hline Begusarai & 0.199 & 0.263 & 0.200 & 32.16 & 31.50 & 36.19 & 23.81 & 34.18 & 899 & 1535 & 850 \\
\hline Darbhanga & 0.200 & 0.251 & 0.202 & 25.50 & 24.25 & 22.29 & 18.47 & 21.12 & 860 & 1401 & 862 \\
\hline Khagaria & 0.195 & 0.233 & 0.199 & 19.48 & 17.08 & 60.00 & 45.47 & 55.59 & 581 & 1542 & 734 \\
\hline Madhubani & 0.207 & 0.250 & 0.209 & 20.77 & 19.61 & 34.62 & 21.06 & 34.24 & 879 & 1507 & 879 \\
\hline Muzaffarpur & 0.253 & 0.380 & 0.260 & 61.66 & 57.30 & 32. 09 & 31.10 & 32.07 & 1035 & 1397 & 916 \\
\hline E. Champaran * & 0.237 & 0.293 & 0.238 & 23.62 & 23.11 & 32.03 & 21.63 & 32.56 & 1229 & 1385 & 1107 \\
\hline Saharsa & 0.287 & 0.292 & 0.286 & 1.74 & 2.09 & 19.17 & 14.59 & 18.15 & 1087 & 1639 & 1155 \\
\hline Samastipur & 0.200 & 0.219 & 0.208 & 9.50 & 5.28 & 42.70 & 21.88 & 41.58 & 839 & 1287 & 866 \\
\hline Sheohar & 0.222 & 0.366 & 0.226 & 64.86 & 61.94 & 38.55 & 22. 32 & 38.11 & 1028 & 1805 & 900 \\
\hline Sitamarhi & 0.227 & 0.287 & 0.229 & 26.43 & 25.32 & 34.58 & 33.82 & 33.91 & 942 & 1383 & 937 \\
\hline Supaul & 0.238 & 0.250 & 0.239 & 5.04 & 4.60 & 20.27 & 14.24 & 20.48 & 1106 & 1474 & 1110 \\
\hline Average all districts & 0.214 & 0.280 & 0.226 & 26.43 & 27.81 & 29.16 & 29.32 & 28.95 & 953 & 1487 & 938 \\
\hline
\end{tabular}

Table 1. Rice water productivity in individual Bihar districts (average 1991-2010).

* E. Champaran = East Champaran (or Purba Champaran). Note: The \% difference of garma rice with kharif and annual rice are derived from [(garma WP/kharif WP $) \times 100]-100$ and [(garma WP/annual WP $) \times 100]-100$ respectively; the \% of coefficient of variation in column 7-9 are derived from [(std. dev. of water productivity for a district/corresponding WP in column 2,3 and 4) $\times 100]$.

The WP of garma rice was higher than that for kharif crops in all districts, with a difference ranging from less than 10\% (in Saharsa, Samastipur and Supaul) to more than $60 \%$ (in Muzaffarpur and Sheohar). In most districts, WP was more variable for kharif rice than for garma rice. This may be because kharif rice is affected by rainfall variability, whereas the water source for garma rice (groundwater) is more dependable.

The overall average rice WP in the Koshi River basin districts of $0.22 \mathrm{~kg} / \mathrm{m}^{3}$ is very low compared to other parts of India such as Haryana $\left(0.40 \mathrm{~kg} / \mathrm{m}^{3}\right)$, and Punjab $\left(0.57 \mathrm{~kg} / \mathrm{m}^{3}\right)$ [20]. WP in Bihar is much lower than the average WP of $0.60-1.60 \mathrm{~kg} / \mathrm{m}^{3}$ in other parts of the world [19,71]. It is even lower than that of Bangladesh $\left(0.30\right.$ to $\left.0.46 \mathrm{~kg} / \mathrm{m}^{3}\right)$, although they have similar biophysical conditions [32]. 


\subsection{Temporal Trend in WP}

The rice WP and rice yield over time in the selected districts are shown in Figure 3a,b. The WP trend over the area as a whole was negative over the twenty-year period. Most individual districts also showed a decreasing trend in WP, but three districts (Darbhanga, Madhubani, and Saharsa) showed a small positive trend. Two of these (Darbhanga and Madhubani) had a very low WP even after the small improvement, but the third (Saharsa) had the highest WP of all districts. The district with the lowest WP (Khagaria) also showed a negative trend over time. The seasonal CWU differences of the selected districts are shown in Figure 3c.

The differences in WP between districts can be attributed in part to a combination of socioeconomic conditions including irrigation facilities, access to electricity, and credit and market facilities, as illustrated by the districts with the highest (Saharsa) and lowest WP (Khagaria). Irrigation coverage in Saharsa and Darbhanga (gross irrigated area of $71 \%$ and $60 \%$, respectively) is much higher than the Bihar average of $41 \%$ [46]. Access to electricity is also higher in Darbhanga, with more than $45 \%$ of villages having power supply, compared to only $36 \%$ for Bihar as a whole [72]. Banking facilities are also better in these two districts. The relatively better irrigation facilities, power supply, and credit facilities contributed to the increased water productivity in the two districts, and the higher agricultural productivity led to higher per capita GDP. Saharsa has a per capita GDP of INR 12,197 compared to INR 11,515 in Khagaria (with the lowest WP) [73]. Flood conditions are also worse in Khagaria, with water logging affecting $8.0 \%$ of the area compared to $4.3 \%$ in Saharsa [74]. Water logging affects crop productivity and reduces water productivity [74]. Handling water logging requires money and technological intervention. As the farmers are poor they have fewer choices, and water and crop management is also poor, eventually resulting in lower yields and WP.

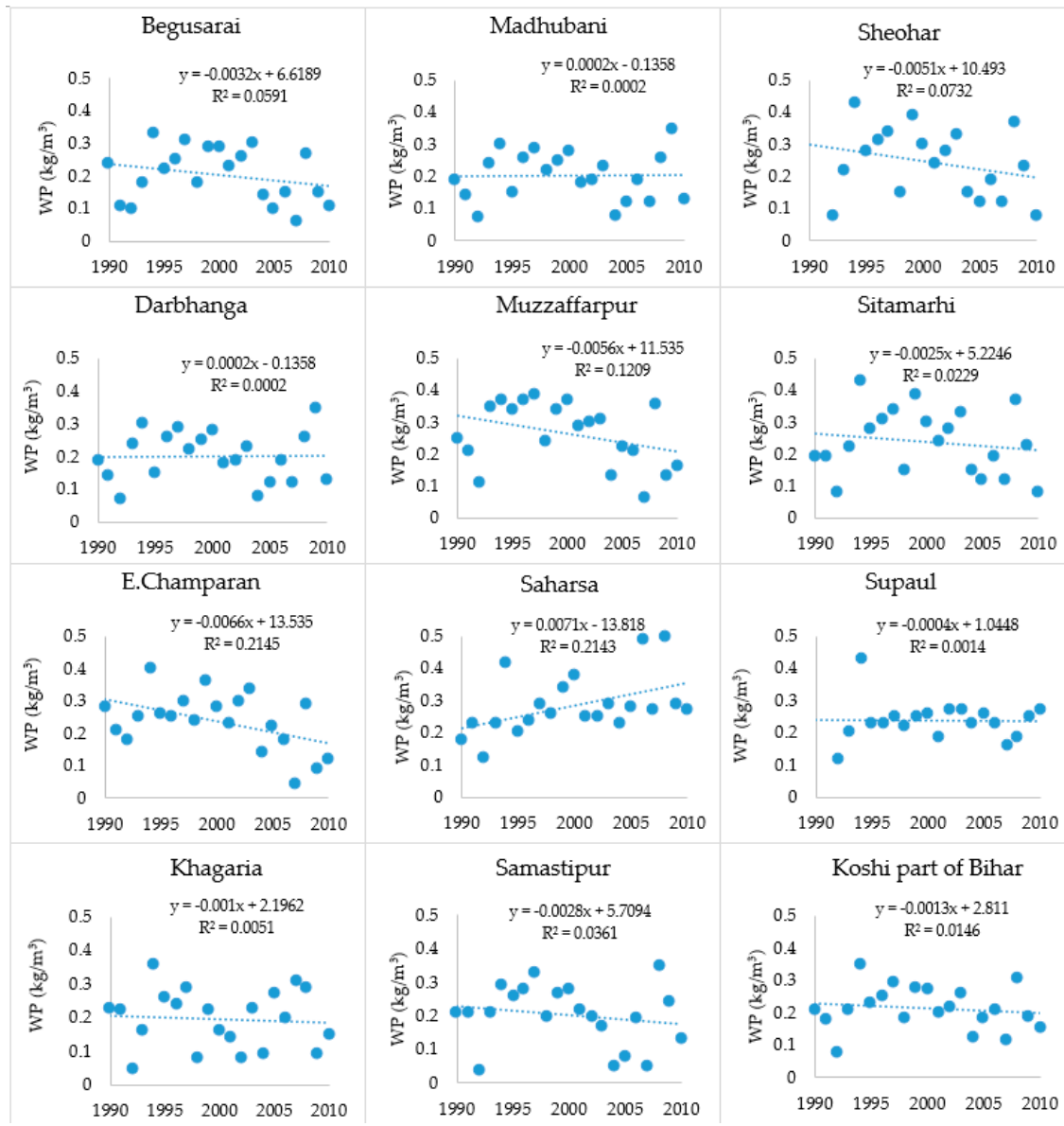

(a)

Figure 3. Cont. 


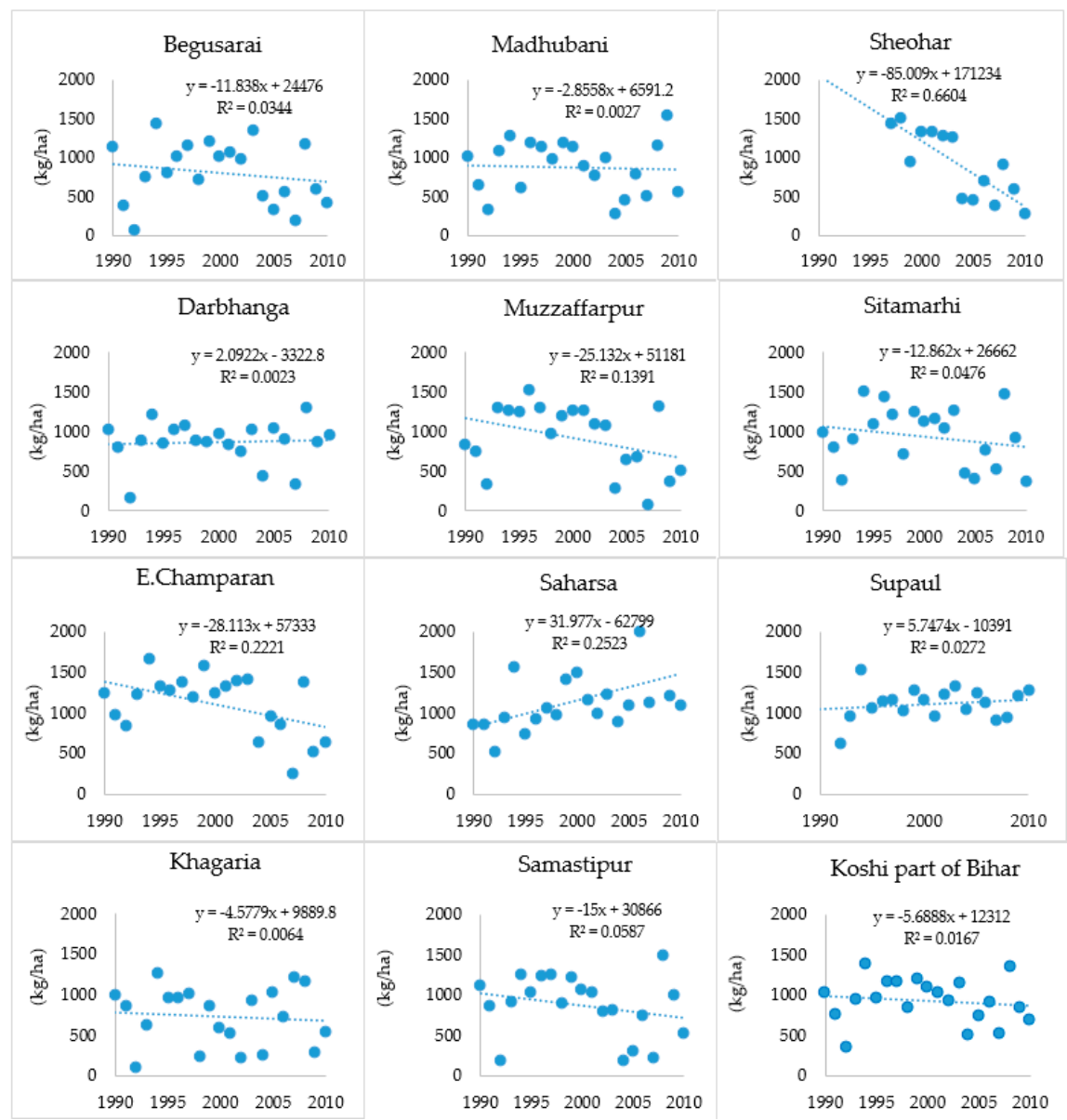

(b)

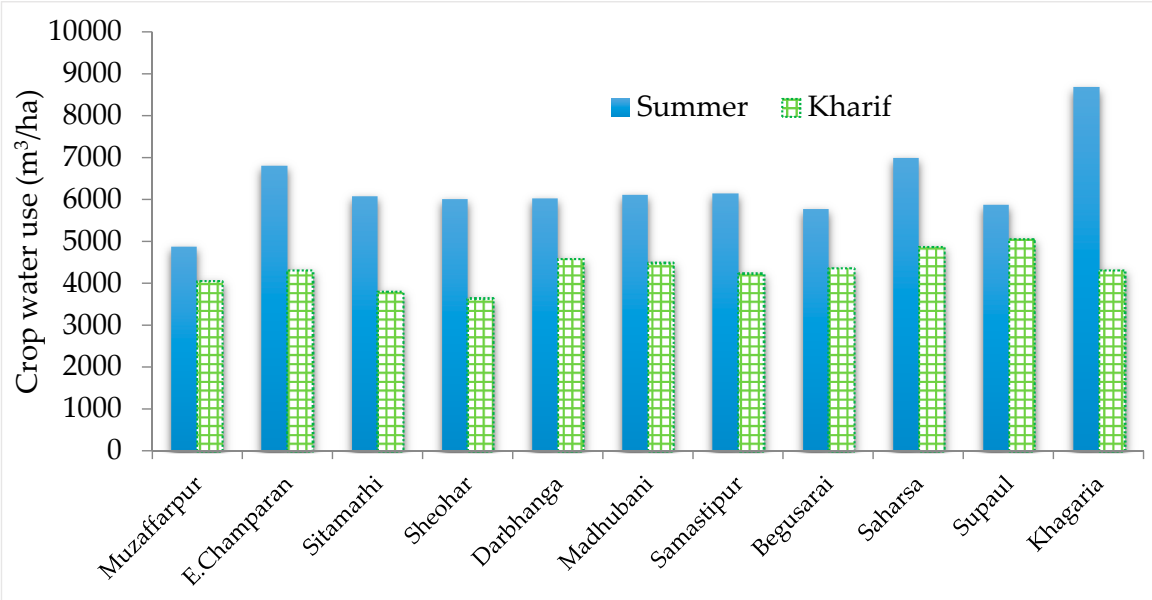

(c)

Figure 3. (a) Rice WP $\left(\mathrm{kg} / \mathrm{m}^{3}\right)$ over time (shown in linear trend lines) in the Koshi districts of Bihar, individually and overall (1991-2010); (b) Rice yield (kg/ha) over time (shown in linear trend lines) in the Koshi districts of Bihar, individually and overall (1991-2010); (c) Consumptive water use in the Koshi districts of Bihar (1991-2010).

\subsection{Season-Wise Consumptive Water Use, Yield, and Marginal Physical Productivity of Water}

The season-wise values for yield, consumptive water use (CWU), WP, and marginal physical productivity (MPP) averaged across the selected 11 districts over the 20-year period are shown in Table 2, and the average monthly values for temperature and ET in Figure 4 . The consumptive water 
use (CWU) of rice is higher in the garma than in the kharif season as a result of the higher temperatures and thus higher ET. However, the yield of rice is also higher in the garma season; thus the WP of garma rice is higher than that of kharif rice. The higher yield and WP of rice in the garma season can be attributed to the more favorable conditions (more sunlight and less disease) and the lower risk of water shortages (as the crop is irrigated) and climate variability. Besides, due to more reliable conditions, farmers are more likely to invest in production inputs, which also lead to higher production.

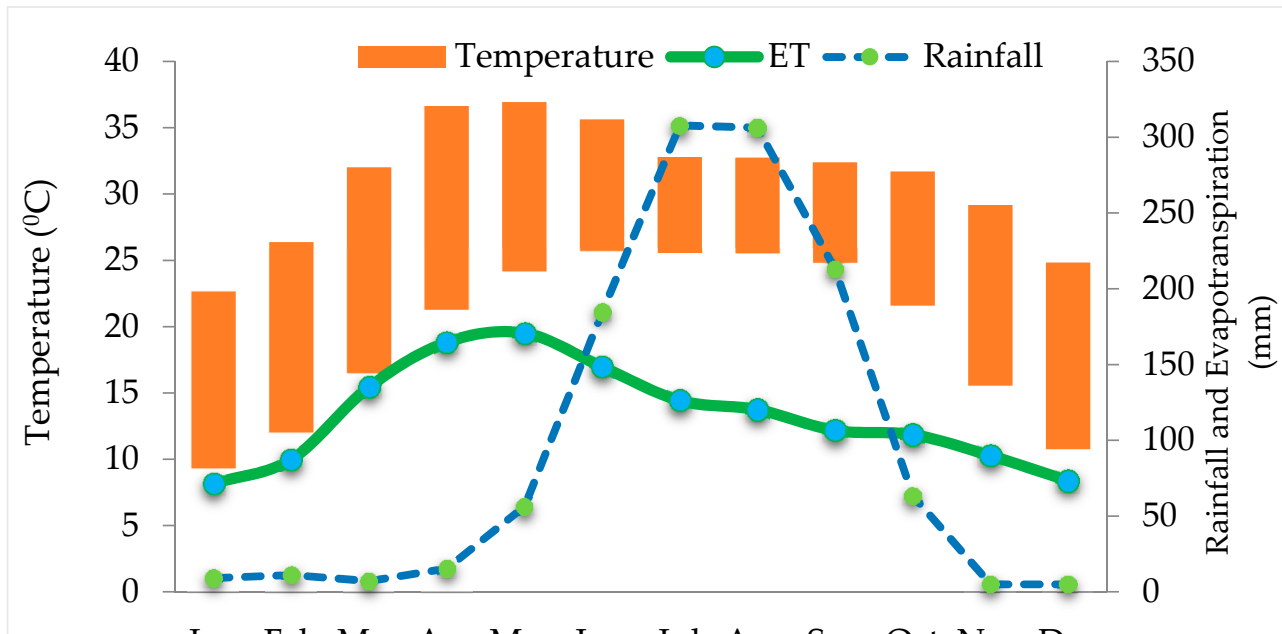

Jan Feb Mar Apr May Jun Jul Aug Sep Oct Nov Dec

Figure 4. Maximum and minimum monthly temperature, mean rainfall and ET in the Koshi river basin districts of Bihar (1991-2010).

The estimates of MPP of water show that use of an additional unit of water may result in an increase of $228 \mathrm{~g}$ in the yield of rice in kharif. However, an additional unit of water may result in higher increase ( $347 \mathrm{~g}$ ) in the yield in garma. It shows that MPP for garma rice is about 52\% higher than for kharif rice (Table 2). In other words, potentially 52\% more rice might be obtained in garma compared to kharif by applying an additional unit of water. Overall, the average annual rice yield of $938 \mathrm{~kg} / \mathrm{ha}$, WP of $0.22 \mathrm{~kg} / \mathrm{m}^{3}$, and MPP of $249 \mathrm{~g} / \mathrm{m}^{3}$ are very low compared to those in garma.

Table 2. Average season-wise rice yield, consumptive water use (CWU), WP, and marginal physical productivity (MPP) in the Koshi districts of Bihar (1991-2010).

\begin{tabular}{lccc}
\hline \multicolumn{1}{c}{ Variables } & Kharif & Garma & Annual \\
\hline Yield $(\mathrm{kg} / \mathrm{ha})$ & 953 & 1487 & 938 \\
CWU $\left(\mathrm{m}^{3} / \mathrm{ha}\right)$ & 4262 & 6151 & 4283 \\
$\mathrm{WP}\left(\mathrm{kg} / \mathrm{m}^{3}\right)$ & 0.21 & 0.28 & 0.22 \\
MPP of water $\left(\mathrm{g} / \mathrm{m}^{3}\right)$ & 228 & 347 & 249 \\
\hline
\end{tabular}

\subsection{Factors Influencing Water Productivity}

The results of the regression model used to analyze the influence of different factors on WP are shown in Table 3. Flood and drought had a statistically significant negative influence on rice WP in the study area, showing that the occurrence of flood or drought will result in low rice WP. In Bihar, rice is mostly grown as a rain-fed crop and climate fluctuation could have a significant impact on yield and WP; flood and drought, which are common, also pose major challenges. In flood-prone areas, water logging and poor drainage system worsen the negative impacts, whereas in drought prone areas, inadequate water conservation technologies add to the problems [75]. 
Cropping intensity also had a statically significant negative influence on WP. Intensification of agriculture requires increased inputs of water and fertilizers. Increasing the cropping intensity without an adequate supply of water and fertilizer may lead to reduced water productivity.

Table 3. Influence of different factors on WP (results of the fixed effects two-stage least square model).

\begin{tabular}{|c|c|c|c|}
\hline \multicolumn{2}{|c|}{ Variable } & Coefficient & SE \\
\hline \multicolumn{2}{|c|}{ Dummy for flood incidence } & $-0.030948^{* *}$ & 0.01563 \\
\hline \multicolumn{2}{|c|}{ Dummy for drought incidence } & $-0.09042^{* * *}$ & 0.02043 \\
\hline \multicolumn{2}{|c|}{ Irrigated area $(\%)$} & $0.00173^{* *}$ & 0.00081 \\
\hline \multicolumn{2}{|c|}{ Cropping intensity $(\%)$} & $-0.00075^{* *}$ & 0.00037 \\
\hline \multicolumn{2}{|c|}{ Fertilizer used in gross cropped area $(\mathrm{kg} / \mathrm{ha})$} & 0.00006 & 0.00015 \\
\hline \multicolumn{2}{|c|}{ HYV in gross cropped area $(\%)$} & 0.00051 & 0.00094 \\
\hline \multicolumn{2}{|c|}{ Constant } & $0.29273^{* * *}$ & 0.069865 \\
\hline \multicolumn{2}{|l|}{ Sigma $u$} & \multicolumn{2}{|c|}{0.03169} \\
\hline \multicolumn{2}{|l|}{ Sigma $e$} & \multicolumn{2}{|c|}{0.08561} \\
\hline \multicolumn{2}{|l|}{ rho } & \multicolumn{2}{|c|}{0.12055} \\
\hline \multirow{3}{*}{ R-square (\%) } & Within & \multicolumn{2}{|c|}{16} \\
\hline & Between & \multicolumn{2}{|c|}{10} \\
\hline & Overall & \multicolumn{2}{|c|}{14} \\
\hline \multicolumn{2}{|c|}{ Wald chi ${ }^{2}(5)$} & \multicolumn{2}{|c|}{ 1341.07 $\left(\right.$ Prob $\left.>\mathrm{chi}^{2}=0.0000\right)$} \\
\hline
\end{tabular}

Instrumented: HYV; instrumental variable: number of agricultural credit accounts

Notes: ${ }^{* * *}$ significant at $1 \%$ level; ${ }^{* *}$ significant at $5 \%$ level. Sigma $u=$ Standard deviation of residuals within groups $u_{i}$; Sigma $e=$ Standard deviation of residuals (overall error term) $e_{i} ;$ rho = Variance due to differences across panels. $\mathrm{SE}=$ Standard Error.

The irrigated area had a positive impact on WP. Extending irrigation facilities, both for supplementary irrigation in the kharif season and for rice cultivation in the garma season, could help increase rice production. However, the problems with irrigation in Bihar include poor infrastructure, inequitable distribution of irrigation water, inadequate numbers of tube wells, ineffective use of rainwater, lack of appropriate storage facilities for rainwater, and inefficient use of irrigation water $[20,29,76]$. Hydrological conditions in the area can support a considerable increase in irrigated area [77]. According to the statistics provided by the Ministry of Water Resources, a total of 22.94 billion cubic meters (BCM) of water is potentially available annually for irrigation in Bihar, while the net draft is around 10.63 BCM/year [78-82]. However, given the small landholdings, poor economic condition of farmers $[29,30]$, and the energy crisis, development of groundwater irrigation is likely to depend on state support, particularly for tube well installation and access to cheaper energy for pumping water. Some evidence can be drawn from the recent Agriculture Package (2015) of Pakistan, which allows interest-free loans (repayment over 10 years) for marginal and small farmers to install solar tube wells or convert existing ones to solar. Under this scheme, 30,000 solar tube wells will be installed in those areas where the water table and quality of groundwater are above standard levels [83]. In Bihar, $62 \%$ of the total irrigated area currently relies on water from tube wells. Most of the tube wells are private, creating an informal water market in which marginal farmers are mostly water buyers [77,84]. Shah [85] argued that the increased cost of groundwater irrigation caused by higher energy prices would affect marginal farmers the most, and some might have to reduce the area cultivated under irrigation, or stop farming altogether.

Fertilizers and sowing of HYV had a positive, although not statistically significant, impact on rice WP. In general, farmers in Bihar do not use adequate amounts of fertilizer as they lack sufficient access to agricultural credit. Also, around $83 \%$ of household cooking fuel comes from biomass-based sources, particularly cow-dung, which is then not available for use as fertilizer [86]. Farming households use only a minute proportion of biomass in their fields and are highly dependent on chemical fertilizers, which most marginal farmers cannot afford. Some studies [87] have reported that Bihar has the highest imbalance in fertilizer use in India. The uncertainty in water availability resulting from poor irrigation 
facilities also impacts decisions on fertilizer use. Farmers are hesitant to spend on farm inputs when water is not assured, and this may explain in part why the relationship between fertilizer use and WP was not significant. The inadequate supply of credit also limits the adoption of HYV, since these crops require more investments in seed, fertilizer, and water.

Rural electrification is very low in Bihar and energy consumption by the agricultural sector is lower than in other rice-growing states and well below the all India average (Table 4). With poor access to electricity, farmers cannot extract sufficient groundwater for irrigation, leading to low water productivity and crop production [72]. In Bihar, only $46 \%$ of the available groundwater is being withdrawn for agriculture (Table 4).

Table 4. Socioeconomy of Bihar in comparison with other major rice growing states in India.

\begin{tabular}{|c|c|c|c|c|c|c|c|}
\hline Variables & Bihar & $\begin{array}{l}\text { Andhra } \\
\text { Pradesh }\end{array}$ & Punjab & $\begin{array}{l}\text { Tamil } \\
\text { Nadu }\end{array}$ & Haryana & $\begin{array}{l}\text { Uttar } \\
\text { Pradesh }\end{array}$ & $\begin{array}{l}\text { All } \\
\text { India }\end{array}$ \\
\hline Marginal farmers (\%) & 90.0 & 61.7 & 13.4 & 76.0 & 47.7 & 78.0 & 64.8 \\
\hline Rural poverty (\%) & 34.1 & 11.0 & 7.7 & 15.3 & 11.6 & 30.4 & 25.7 \\
\hline $\begin{array}{l}\text { Monthly rural per capita income } \\
\left(\text { INR }^{\mathrm{a}}\right)\end{array}$ & 778 & 860 & 1054 & 880 & 1015 & 768 & 816 \\
\hline Infrastructure index & 81.3 & 103.3 & 187.5 & 149.1 & 137.5 & 101.2 & - \\
\hline Credit flow to agriculture (Rs/ha) & 8880 & 23,441 & 46,593 & 52,427 & 34,012 & 29,065 & 15,936 \\
\hline $\begin{array}{l}\text { Money sanctioned with Kisan credit } \\
\text { care scheme (Rs/ha) }\end{array}$ & 5807 & 6219 & 16,939 & 14,318 & 9243 & 7967 & 5744 \\
\hline $\begin{array}{l}\text { Use of available ground water for } \\
\text { irrigation }(\%)^{b}\end{array}$ & 46 & 28 & 97 & 86 & 112 & 47 & 41 \\
\hline Rural HH electrification (\%) & 10 & 90 & 95 & 91 & 87 & 24 & 55 \\
\hline $\begin{array}{l}\text { Agricultural sector share of } \\
\text { electricity consumption (\%) }\end{array}$ & 13.3 & 31.5 & 33.5 & 20.7 & 40.3 & 17.6 & 21.0 \\
\hline Rice yield (kg/ha) & 1120 & 3062 & 4010 & 3070 & 3008 & 2084 & 2125 \\
\hline
\end{tabular}

Table 4 shows various socioeconomic indicators for Bihar in comparison with other major rice growing states in India. They show the reasons why rice yield and WP are lower in Bihar than in the other major rice growing states. Bihar has the highest levels of rural poverty and lowest rural per capita income of all these states. It is likely that farmers cannot afford the high costs of irrigation and cultivation, and have a low ability to bear risk. They are less likely to invest in inputs and adopt new technologies, which leads to inefficiency in resource use and increases the gap between actual and potential yield [88-90]. Better access to agricultural credit could help increase the ability of farmers to bear risk [88]. However, the general credit supply (per hectare credit flow to agriculture) and special credit to procure agricultural inputs (per hectare credit sanctioned through the Kisan Credit Card Scheme) are also low in Bihar compared to other states (Table 4). Due to inadequate access to agricultural credit, farmers may face difficulties in making timely investments for inputs and irrigation.

\section{Conclusions}

This study investigated the underlying causes of low rice WP in the Koshi River basin districts of Bihar by taking a multidisciplinary approach. As expected, our analysis found that rice WP in Bihar is very low compared to other parts in India and other countries with similar biophysical conditions. Surprisingly, WP varies considerably among different districts in Bihar. However, in all the districts, except Saharsa, a common trend is that the WP is declining over time. In Saharsa, WP is relatively high, and in Darbhanga WP is relatively low and only showed a very small increase over time. 
Among the factors, irrigation had a statistically significant positive influence on rice WP, and incidence of flood and drought, and cropping intensity had significant negative influence. The question is why WP is increasing in Saharsa, and to a lesser extent in Darbhanga, while it is decreasing in other districts. Although both Saharsa and Darbanga are highly flood prone, have relatively better irrigation facilities and better power supply contributed to the gradual increase in WP. A decrease in WP in other districts is attributed to insufficient irrigation resulting from underutilization of groundwater due to limited access to electricity. Due to the lack of irrigation facilities, rice is largely grown as a rain-fed crop and variations in precipitation have a substantial impact on productivity. Rice yield and WP were low in both the garma (non-monsoon) and kharif seasons, but were relatively higher in the garma season, because of the greater reliability of the water supply when crops are irrigated, as well as the lower risk of climate induced hazards in terms of floods and drought in the dry season. The marginal physical productivity of water is 1.5 times higher in garma season compared to the kharif season. To sum up, irrigation facilities positively influence rice WP and floods and droughts negatively influence rice WP.

The findings of the study have important implications for improving rice WP in Bihar and similar areas in other parts of South Asia. It is clear that there is a considerable scope to improve water productivity in Bihar if appropriate measures are taken. Based on the study findings, we suggest the following course of action to improve rice WP in Bihar.

- Irrigation facilities and irrigation quality need to be improved so that farmers can increase the area under rice during the garma (dry) season when there is no flood risk and the growing conditions for rice are better. Experiences from Bangladesh suggest that rice productivity can be improved by increasing irrigation facilities in the dry season [32].

- Apart from surface water irrigation, efforts could be made to enhance ground water irrigation facilities for timely and adequate supply of water for irrigation. At present, only $46 \%$ of available groundwater is being utilized in Bihar. Where electricity is not available, solar powered irrigation system could be arranged. Improved groundwater irrigation will also help in coping with drought spells.

- Improving the supply of credit for agricultural development (for tube well installation, especially solar) and production loans (for inputs) will also help farmers to meet their irrigation needs and procure inputs such as fertilizers. The combination of an adequate supply of water and balanced use of fertilizer will reduce the effect of cropping intensity on soil moisture and fertility, and contribute to improving yield and water productivity.

Author Contributions: In this article, O.N. formulated the research design, collected and analyzed data, and contributed to the interpretation of results and writing; G.R. contributed to the research design, interpretation of results and writing, A.H. conducted the econometric analysis of the panel data, interpreted the results and contributed to writing; D.M. contributed to analysis, writing and policy implications; S.W. contributed to the analysis of hydro-meteorological data and modeling; and, B.D. contributed to the applications of GIS software and preparation of the map.

Funding: This study was part of the Koshi Basin Programme of International Centre for Integrated Mountain Development (ICIMOD) funded by the Department of Foreign Affairs and Trade (DFAT) of Australia. The authors also gratefully acknowledge the support of core donors of ICIMOD: the governments of Afghanistan, Australia, Austria, Bangladesh, Bhutan, China, India, Myanmar, Nepal, Norway, Pakistan, Switzerland, and the UK.

Acknowledgments: Authors would like to thank the academic editor and two anonymous reviewers for their highly valuable input. They would also like to thank their two ICIMOD colleagues-Thomas Samuel Moloppomannil for his editorial input and Mohd Abdul Fahad for his technical support in presentation of graphs. The views and interpretations in this paper are those of the authors. They are not attributable to their organizations.

Conflicts of Interest: The authors declare no conflicts of interest. 


\section{References}

1. Jiang, Y.; Xu, X.; Huang, Q.; Huo, Z.; Huang, G. Assessment of irrigation performance and water productivity in irrigated areas of the middle Heihe River basin using a distributed agro-hydrological model. Agric. Water Manag. 2015, 147, 67-81. [CrossRef]

2. Chartres, C. Is water scarcity a constraint to feeding Asia's growing population? Int. J. Water Resour. Dev. 2014, 30, 28-36. [CrossRef]

3. Kumar, M.D.; Turral, H.; Sharma, B.; Amarasinghe, U.; Singh, O.P. Water saving and yield enhancing micro irrigation technologies in India: When and where can they become best bet technologies. In Managing Water in the Face of Growing Scarcity, Inequity and Declining Returns: Exploring Fresh Approaches; International Water Management Institute (IWMI): Colombo, Sri Lanka, 2008; Volume 1, pp. 1-36.

4. Du, T.; Kang, S.; Sun, J.; Zhang, X.; Zhang, J. An improved water use efficiency of cereals under temporal and spatial deficit irrigation in north China. Agric. Water Manag. 2010, 97, 66-74. [CrossRef]

5. Rasul, G. Food, water, and energy security in South Asia: A nexus perspective from the Hindu Kush Himalayan region. Environ. Sci. Policy 2014, 39, 35-48. [CrossRef]

6. Jehangir, W.A.; Masih, I.; Ahmed, S.; Gill, M.A.; Ahmad, M.; Mann, R.A.; Chaudhary, M.R.; Qureshi, A.S.; Turral, H. Sustaining Crop Water Productivity in Rice-Wheat Systems of South Asia: A Case Study from the Punjab, Pakistan; IWMI: Colombo, Sri Lanka, 2007.

7. Molden, D.; Sakthivadivel, R. Water accounting to assess use and productivity of water. Int. J. Water Resour. Dev. 1999, 15, 55-71. [CrossRef]

8. Miao, Q.; Shi, H.; Gonçalves, J.M.; Pereira, L.S. Basin irrigation design with multi-criteria analysis focusing on water saving and economic returns: Application to wheat in Hetao, Yellow River Basin. Water 2018, 10, 67. [CrossRef]

9. De Fraiture, C.; Wichelns, D. Satisfying future water demands for agriculture. Agric. Water Manag. 2010, 97, 502-511. [CrossRef]

10. Djaman, K.; O’Neill, M.; Owen, C.K.; Smeal, D.; Koudahe, K.; West, M.; Allen, S.; Lombard, K.; Irmak, S. Crop evapotranspiration, irrigation water requirement and water productivity of maize from meteorological data under semiarid climate. Water 2018, 10, 405. [CrossRef]

11. Karimi, P.; David, M.; Bastiaanssen, W. Mapping crop water productivity in the Nile basin through combined use of remote sensing and census data. In Proceedings of the ICID 21st Congress on Irrigation and Drainage: Water Productivity towards Food Security, Tehran, Iran, 15-23 October 2011; pp. 137-148.

12. Molden, D.; Oweis, T.; Steduto, P.; Bindraban, P.; Hanjra, M.A.; Kijne, J. Improving agricultural water productivity: Between optimism and caution. Agric. Water Manag. 2010, 97, 528-535. [CrossRef]

13. Kijne, J.W.; Barker, R.; Molden, D. Improving water productivity in agriculture: Editors' overview. In Water Productivity in Agriculture: Limits and Opportunities for Improvement; IWMI: Colombo, Sri Lanka, 2003.

14. Mo'allim, A.A.; Kamal, M.R.; Muhammed, H.H.; Wayayok, A. An assessment of the vertical movement of water in a flooded paddy rice field experiment using hydrus-1D. Water 2018, 10, 783. [CrossRef]

15. Rosegrant, M.W.; Ringler, C.; Gerpacio, R.V. Water and land resources and global food supply. In Proceedings of the 1997 International Association of Agricultural Economists Conference, Sacramento, CA, USA, 10-16 August 1997.

16. Godfrey, J.M.; Chalmers, K. (Eds.) Water Accounting: International Approaches to Policy and Decision-Making; Edward Elgar Publishing: Cheltenham, UK, 2012.

17. Gleick, P.H. Water and conflict: Fresh water resources and international security. Int. Secur. 1993, 18, 79-112. [CrossRef]

18. Frenken, K. Irrigation in Southern and Eastern Asia in Figures: AQUASTAT Survey-2011; FAO Water Report No. 37; FAO Land and Water Division: Rome, Italy, 2012.

19. Zwart, S.J.; Bastiaanssen, W.G. Review of measured crop water productivity values for irrigated wheat, rice, cotton and maize. Agric. Water Manag. 2004, 69, 115-133. [CrossRef]

20. Sharma, B.R.; Gulati, A.; Mohan, G.; Manchanda, S.; Ray, I.; Amarasinghe, U. Water Productivity Mapping of Major INDIAN Crops; National Bank for Agriculture and Rural Development (NABARD): Mumbai, India; Indian Council for Research on International Economic Relations (ICRIER): New Delhi, India, 2018.

21. Neupane, N.; Murthy, M.S.; Rasul, G.; Wahid, S.; Shrestha, A.B.; Uddin, K. Integrated biophysical and socioeconomic model for adaptation to climate change for agriculture and water in the Koshi Basin. In Handbook of Climate Change Adaptation; Springer: Berlin, Germany, 2013; pp. 1-23. 
22. Bihar through Figures 2011; Government of Bihar, Directorate of Economics \& Statistics: Patna, India, 2011. Available online: http:/ / dse.bih.nic.in/New-Publications/Bihar\%20Through\%20figures\%202011.pdf (accessed on 16 June 2015).

23. Salam, M.A.; Anwer, M.E.; Alam, M.S. Agriculture and the economy of Bihar: An analysis. Int. J. Sci. Res. Publ. 2013, 3. Available online: http:/ / citeseerx.ist.psu.edu/viewdoc/download?doi=10.1.1.403.2781\&rep= rep1\&type $=$ pdf $\#$ page $=696$ (accessed on 17 June 2015).

24. Pandey, S.; Pal, S. The nature and causes of changes in variability of rice production in eastern India: A district-level analysis. In Risk Analysis and Management in Rainfed Rice Systems; International Rice Research Institute (IRRI): Los Baños, Philippines, 2000.

25. Kishore, A. Understanding agrarian impasse in Bihar. Econ. Polit. Wkly. 2004, 31, 3484-3491.

26. Thakur, J.; Bose, M.L.; Hossain, M.; Janaiah, A. Rural income distribution and poverty in Bihar: Insights from village studies. Econ. Polit. Wkly. 2000, 30, 4657-4663.

27. Behera, D.; Chaudhary, A.K.; Vutukuru, V.K.; Gupta, A.; Machiraju, S.; Shah, P. Enhancing Agricultural Livelihoods through Community Institutions in Bihar, India; South Asia Livelihoods Learning Note Series 3 Note 1; The World Bank: Washington, DC, USA, 2013.

28. Ramagundam, R. Complexities in natural-resource management: Irrigation infrastructure in Bihar. Dev. Pract. 2009, 19, 16-27. [CrossRef]

29. Singh, K.M.; Singh, R.K. Rice in Bihar-An economic analysis with special reference to Boro rice. Agric. Situat. India 2000, 56, 677-682.

30. Bhattarai, M.; Narayanamoorthy, A. Impact of irrigation on rural poverty in India: An aggregate panel-data analysis. Water Policy 2003, 5, 443-458. [CrossRef]

31. Guerra, L.C. Producing More Rice with Less Water from Irrigated Systems; IWMI: Colombo, Sri Lanka, 1998.

32. Alauddin, M.; Sharma, B.R. Inter-district rice water productivity differences in Bangladesh: An empirical exploration and implications. Ecol. Econ. 2013, 93, 210-218. [CrossRef]

33. Cai, X.; Thenkabail, P.S.; Biradar, C.M.; Platonov, A.; Gumma, M.; Dheeravath, V.; Cohen, Y.; Goldshleger, N.; Ben-Dor, E.; Alchanatis, V.; et al. Water productivity mapping using remote sensing data of various resolutions to support "more crop per drop". J. Appl. Remote Sens. 2009, 3, 033557. [CrossRef]

34. Platnonov, A.; Thenkabail, P.S.; Biradar, C.M.; Cai, X.; Gumma, M.; Dheeravath, V.; Cohen, Y.; Alchanatis, V.; Goldshlager, N.; Ben-Dor, E.; et al. Water productivity mapping (WPM) using landsat ETM+ data for the irrigated croplands of the Syrdarya River basin in Central Asia. Sensors 2008, 8, 8156-8180. [CrossRef] [PubMed]

35. Cai, X.; Molden, D.; Mainuddin, M.; Sharma, B.; Ahmad, M.U.; Karimi, P. Producing more food with less water in a changing world: Assessment of water productivity in 10 major river basins. Water Int. 2011, 36, 42-62. [CrossRef]

36. Mati, B.M. Limitations to the use of remote sensing technology in Kenya. In Space of Service to Humanity; Springer: Dordrecht, The Netherlands, 1997; pp. 187-195.

37. Cook, S.; Gichuki, F.; Turral, H. Water productivity: Estimation at plot, farm and basin scale. In People and Agro-Ecosystems Research for Development Challenge; CIAT: Cali, Colombia, 2006; p. 144.

38. Cai, X.L.; Sharma, B.R. Integrating remote sensing, census and weather data for an assessment of rice yield, water consumption and water productivity in the Indo-Gangetic river basin. Agric. Water Manag. 2010, 97, 309-316. [CrossRef]

39. Ladha, J.K.; Pathak, H.; Tirol-Padre, A.; Dawe, D.; Gupta, R.K. Productivity trends in intensive rice-Wheat cropping systems in Asia. In Improving the Productivity and Sustainability of Rice-Wheat Systems: Issues and Impacts; American Society of Agronomy: Madison, WI, USA, 2003; pp. 45-76.

40. Singh, Y. Direct Seeding of Rice and Weed Management in the Irrigated Rice-Wheat Cropping System of the Indo-Gangetic Plains; IRRI: Los Baños, Philippines, 2008.

41. Bansil, P.C. Bihar Agriculture: A perspective; Concept Publishing Company: New Delhi, India, 2011.

42. Redfern, S.K.; Azzu, N.; Binamira, J.S. Rice in Southeast Asia: Facing risks and vulnerabilities to respond to climate change. In Building Resilience for Adaptation to Climate Change in the Agriculture Sector; Proceedings of a Joint FAO/OECD Workshop, Rome, Italy, 23-24 April 2012; Food and Agriculture Organization: Rome, Italy, 2012; p. 295.

43. Clarke-Sather, A.; Tang, X.; Xiong, Y.; Qu, J. The impact of green water management strategies on household-level agricultural water productivity in a semi-arid region: A survey-based assessment. Water 2017, 10, 11. [CrossRef] 
44. Klatzel, F.; Murray, A.B. Local Responses to Too Much and Too Little Water in the Greater Himalayan Region; International Centre for Integrated Mountain Development: Kathmandu, Nepal, 2009.

45. Rice in India: A Status Paper; Directorate of Rice Development: Patna, India, 2012; Available online: http: / / drdpat.bih.nic.in/Downloads/Status-Paper-on-Rice.pdf (accessed on 11 May 2015).

46. Government of Bihar, Department of Agriculture. Available online: http://www.krishi.bih.nic.in/ (accessed on 6 May 2015).

47. Bihar Statistical Hand Book; Government of Bihar, Directorate of Economics \& Statistics, Department of Planning \& Development: Patna, India, 2012.

48. Bihar Statistical Hand Book; Government of Bihar, Directorate of Economics \& Statistics, Department of Planning \& Development: Patna, India, 2011.

49. Bihar Statistical Hand Book; Government of Bihar, Directorate of Economics \& Statistics, Department of Planning \& Development: Patna, India, 2010.

50. Bihar Statistical Hand Book; Government of Bihar, Directorate of Economics \& Statistics, Department of Planning \& Development: Patna, India, 2006.

51. Allen, R.G.; Pereira, L.S.; Raes, D.; Smith, M. Crop Evapotranspiration-Guidelines for Computing Crop Water Requirements-FAO Irrigation and Drainage Paper 56; FAO: Rome, Italy, 1998. Available online: http: / /www. districtsofindia.com/punjab/alldistricts/economy/index.aspx (accessed on 14 August 2018).

52. Government of Bihar, Department of Disaster Management. Available online: http:/ / disastermgmt.bih.nic.in (accessed on 16 August 2015).

53. Singh, R.; Van Dam, J.C.; Feddes, R.A. Water productivity analysis of irrigated crops in Sirsa district, India. Agric. Water Manag. 2006, 82, 253-278. [CrossRef]

54. Zhan, J.; Sun, Z.; Wang, Z.; Chen, J.; Li, Z. Simulated water productivity in Gansu Province, China. Phys. Chem. Earth Parts $A / B / C$ 2015, 79, 67-75. [CrossRef]

55. Molden, D.J.; Sakthivadivel, R.; Perry, C.J.; De Fraiture, C.; Kloezen, W.H. Indicators for Comparing Performance of Irrigated Agricultural Systems; Research report 20; IWMI: Colombo, Sri Lanka, 1998; pp. 1-26.

56. Amarasinghe, U.A.; Shah, T.; Singh, O.P. Changing Consumption Patterns: Implications on Food and Water Demand in India; IWMI: Colombo, Sri Lanka, 2007.

57. Smith, M. CROPWAT: A Computer Program for Irrigation Planning and Management; FAO: Rome, Italy, 1992.

58. Arowolo, A.O.; Bhowmik, A.K.; Qi, W.; Deng, X. Comparison of spatial interpolation techniques to generate high-resolution climate surfaces for Nigeria. Int. J. Climatol. 2017, 39, 179-192. [CrossRef]

59. Deng, X. Modeling the Dynamics and Consequences of Land System Change; Springer: Berlin, Germany, 2011; pp. 257-261. Available online: https:/ /link.springer.com/book/10.1007\%2F978-3-642-15447-8 (accessed on 23 June 2015).

60. Deng, X.; Su, H.; Zhan, J. Integration of multiple data sources to simulate the dynamics of land systems. Sensors 2008, 8, 620-634. [CrossRef] [PubMed]

61. Zhuang, D.F.; Liu, M.L.; Deng, X.Z. Spatialization model of population based on dataset of land use and land cover change in China. Chin. Geogr. Sci. 2002, 12, 114-119. [CrossRef]

62. Geist, H.J.; Lambin, E.F. Proximate causes and underlying driving forces of tropical deforestation: Tropical forests are disappearing as the result of many pressures, both local and regional, acting in various combinations in different geographical locations. BioScience 2002, 52, 143-150. [CrossRef]

63. Najmuddin, O.; Deng, X.; Bhattacharya, R. The dynamics of land use/cover and the statistical assessment of cropland change drivers in the Kabul River Basin, Afghanistan. Sustainability 2018, 10, 423. [CrossRef]

64. Najmuddin, O.; Deng, X.; Siqi, J. Scenario analysis of land use change in Kabul River Basin-A river basin with rapid socio-economic changes in Afghanistan. Phys. Chem. Earth 2017, 101, 121-136. [CrossRef]

65. Young, R.A.; Gray, S.L. Economic Value of Water: Concepts and Empirical Estimates; Final Report to the National Water Commission; U.S. National Water Commission: Arlington, VA, USA; National Technical Information Service: Springfield, VA, USA, 1972.

66. Omezzine, A.; Zaibet, L.; Omezzine, A.; Zaibet, L. Management of modern irrigation systems in Oman: Allocative vs. irrigation efficiency. Agric. Water Manag. 1998, 37, 99-107. [CrossRef]

67. Ekanayake, S.A.; Jayasuriya, S.K. Measurement of firm-specific technical efficiency: A comparison of methods. Agric. Econ. 1987, 38, 115-122. [CrossRef]

68. Baltagi, B. Econometric Analysis of Panel Data; John Wiley \& Sons: New York, NY, USA, 2008. 
69. Schmidheiny, K. Panel data: Fixed and random effects. In Short Guides to Microeconometrics; Unversität Basel: Basel, Switzerland, 2011.

70. Stata Longitudinal-Data/Panel-Data Reference Manual: Release 11; Stata Press: Texas, TX, USA, 2009.

71. Cai, X.; Rosegrant, M.W. 10 world water productivity: Current situation and future options. In Water Productivity in Agriculture: Limits and Opportunities for Improvement; Kijne, J.W., Barker, R., Molden, D., Eds.; International Food Policy Research Institute: Washington, DC, USA, 2003; Volume 1, p. 163.

72. IHD (Institute for Human Development). Baseline Survey of Minority Concentration District of India, Darbhanga, Bihar; Ministry of Minority Affairs: New Delhi, India; Government of India: New Delhi, India; ICAR: New Delhi, India, 2008.

73. Economic Survey of Bihar, 2013-14; Finance Department, Government of Bihar: Patna, India, 2014.

74. Efficiency of Land Use-Temporal and Spatial Analysis with Policy and Planning Implication; Directorate of Evaluation, Department of Planning and Development, Government of Bihar: Patna, India, 2014.

75. All India Report on Number and Area of Operational Holding; Agricultural Census Division, Department of Agriculture and Cooperation, Ministry of Agriculture, Government of India: New Delhi, India, 2014.

76. Press Note on Poverty Estimates in India; Planning Commission, Government of India: New Delhi, India, 2013.

77. Wood, G. Private provision after public neglect: Bending irrigation markets in North Bihar. Dev. Chang. 1999, 30, 775-794. [CrossRef]

78. Gandhi, V.P.; Namboodiri, N.V. Groundwater Irrigation in India: Gains, Costs and Risks; IIMA: Ahmedabad, India, 2009.

79. Chatterjee, R.; Purohit, R.R. Estimation of replenishable groundwater resources of India and their status of utilization. Curr. Sci. 2009, 25, 1581-1591.

80. Rajmohan, N.; Prathapar, S.A. Hydrogeology of the Eastern Ganges Basin: An Overview; IWMI: Colombo, Sri Lanka, 2013.

81. Ground Water Information Booklet: Darbhanga District, Bihar State; Central Ground Water Board, Ministry of Water Resources, Mid-Eastern Region: Patna, India, 2013.

82. Groundwater Resource Estimation Methodology-Report of the Groundwater Resource Estimation Committee; Ministry of Water Resources: New Delhi, India, 2009.

83. Agriculture Package 2015, Pakistan. Prime Minister's Office, Islamabad. Government of Pakistan. 2015. Available online: http: / / www.pmo.gov.pk/news_details.php?news_id=418 (accessed on 23 June 2015).

84. Mukherji, A. Spatio-temporal analysis of markets for groundwater irrigation services in India: 1976-1977 to 1997-1998. Hydrogeol. J. 2008, 16, 1077-1087. [CrossRef]

85. Shah, T.; Hassan, M.U.; Khattak, M.Z.; Banerjee, P.S.; Singh, O.P.; Rehman, S.U. Is irrigation water free? A reality check in the Indo-Gangetic Basin. World Dev. 2009, 37, 422-434. [CrossRef]

86. Garg, A.; Geol, A.; Mohan, P.; Homberg van den, H. Cooking with Cleaner Fuels in India: A Strategic Analysis and Assessment. 2010. Available online: http://www.teriin.org/div/CES/Policy_brief_cooking_fuels.pdf (accessed on 19 July 2015).

87. Chand, R.; Pandey, L.M. Fertiliser Growth, Imbalances and Subsidies: Trends and Implications; National Centre for Agricultural Economics and Policy Research: New Delhi, India, 2008. Available online: http:/ /www. ncap.res.in/upload_files/others/Oth_21.pdf (accessed on 14 April 2015).

88. Bista, D.R.; Kumar, P.; Mathur, V.C. Progress and Performance of Kisan Credit Card Scheme with a Case Study of Bihar. Agric. Econ. Res. Rev. 2012, 25, 125-135.

89. Kumar, A.; Singh, K.M.; Sinha, S. Institutional Credit to Agriculture Sector in India: Status, Performance and Determinants. Agric. Econ. Res. Rev. 2012, 23, 253-264.

90. Mohan, R. Agricultural credit in India: Status, issues and future agenda. Econ. Polit. Wkly. 2006, 18, 1013-1023.

91. Agriculture Statistics at Glance. Available online: http:/ / eands.dacnet.nic.in/latest_20011.htm (accessed on 17 November 2015).

(C) 2018 by the authors. Licensee MDPI, Basel, Switzerland. This article is an open access article distributed under the terms and conditions of the Creative Commons Attribution (CC BY) license (http://creativecommons.org/licenses/by/4.0/). 